\author{
V.E. GROMOV ${ }^{1, *}$, YU.F. IVANOV ${ }^{2}$, V.E. KORMYSHEV ' \\ A.A. YURIEV ${ }^{3}$, A.P. SEMIN ${ }^{1, * *}$, and YU.A. RUBANNIKOVA' \\ ' Siberian State Industrial University, \\ 42 Kirov Str., 654007 Novokuznetsk, Russia \\ ${ }^{2}$ Institute of High-Current Electronics, SB RAS, \\ 2/3 Akademicheskiy Ave., 634055 Tomsk, Russia \\ 3 JSC 'Evraz-West-Siberian Metallurgical Combine', \\ 19 Kosmicheskoe Hgwy., 654043 Novokuznetsk, Russia \\ *gromov@physics.sibsiu.ru,** syomin53@gmail.com
}

\title{
CHANGE IN STRUCTURAL-PHASE STATES AND PROPERTIES OF LENGTHY RAIS DURING EXTREMELY LONG-TERM OPERATION
}

The regularities and formation mechanisms of structural-phase states and properties at different depths in the rail heads along the central axis and fillet after differential quenching of 100-meter rails and extremely long operation (with passed tonnage of 1411 million tons gross weight) have been revealed by the methods of the state-of-the-art physical materials science. As revealed, the differential quenching is accompanied by the formation of morphologically multi-aspect structure presented by grains of lamellar perlite, ferrite-carbide mixture, and structure-free ferrite. The steel structure is characterized by the $\alpha$-Fe lattice parameter, the level of microstresses, the size of coherent-scattering region, the value of interlamellar distance, the scalar and excess dislocation densities. As shown, the extremely long operation of rails is accompanied by the numerous transformations of metal structure of rail head: firstly, a fracture of lamellar pearlite structure and a formation of subgrain structure of submicron (100-150 $\mathrm{nm}$ ) sizes in the bulk of pearlite colonies; secondly, a precipitation of carbide phase particles of nanometer range along the boundaries and in the bulk of subgrains; thirdly, a microdistortion growth of steel crystal lattice; fourthly, a strain hardening of metal resulting in the increase (by 1.5 -fold) in scalar and excess dislocation densities relative to the initial state. A long-term operation of rails is accompanied by the formation of structural constituent gradient consisting in a regular change in the relative content of lamellar pear-

Citation: V.E. Gromov, Yu.F. Ivanov, V.E. Kormyshev, A.A. Yuriev, A.P. Semin, and Yu.A. Rubannikova, Change in Structural-Phase States and Properties of Lengthy Rails during Extremely Long-Term Operation, Progress in Physics of Metals, 21, No. 4: 527-553 (2020) 
lite, fractured pearlite, and structure of ferrite-carbide mixture along cross-section of rail head. As the distance to the rail fillet surface decreases, a relative content of metal volume with lamellar pearlite decreases, and that with the structure of fractured pearlite and ferrite-carbide mixture increases. As determined, the characteristic feature of ferrite-carbide mixture structure is a nanosize range of grains, subgrains and carbide-phase particles forming it. The size of grains and subgrains forming the type of structure varies in the limits of $40-70 \mathrm{~nm}$; the size of carbidephase particles located along the boundaries of grains and subgrains varies in the limits of 8-20 nm. A multiaspect character of steel strengthening is detected that is caused by several factors: firstly, the substructural strengthening due to the formation of fragment subboundaries, whose boundaries are stabilized by the carbidephase particles; secondly, the strengthening by carbide-phase particles located in the bulk of fragments and on elements of dislocation substructure (dispersion hardening); thirdly, the strengthening caused by the precipitation of carbon atoms on dislocations (formation of Cottrell atmospheres); fourthly, the strengthening being introduced by internal stress fields due to incompatibility of crystal-lattices' deformation of $\alpha$-phase structural constituents and carbide-phase particles.

Keywords: rails, micro-nanocrystalline structure, lamellar pearlite, long operation, mechanisms of hardening.

\section{Introduction}

The increase in the intensity of railway transport and freight traffic causes the necessity of further increase in operation resistance of rails. The problem of formation and evolution of rail structure and properties in long-term operation is a complex system of interconnected scientific and technical problems. Taking into account that kinetics of formation processes of structural phase states is connected with the fundamentals of the theory of strength and plasticity, the information on the parameters of rail fine structure in different cross-sections is of crucial importance. The consideration of rails' behaviour in long operation and the analysis of reasons for their withdrawal have recently been of great interest. The expansion of information in this field is connected with both an attempt to a deeper understanding of fundamental problems of physical materials science and a practical importance being dictated by the continuous growth of requirements to the reliability of rails in modern conditions of high loads on axis and rates of motion [1, 2]. It is obvious that under intensive deformation effects being realized in long-term operation the different processes (recrystallization, relaxation, phase transitions, decay and formation of phases, amorphization, etc.) leading to the evolution of structural phase states being accompanied by the change (deterioration) in mechanical properties [3-8] may occur.

The issues connected with the wear of rails have recently been surveyed in detail in Russian and foreign literature. It is proved that wear defects are initially formed in the surface layers; in this case, the begin- 
ning of the permanent wear coincides with the accumulation of definite level of plastic deformation [9-14]. In long-term operation, the irregular high value of microhardness and the phenomenon of strain-induced decay of cementite, stable in normal conditions, are observed on the surface. The knowledge of regularities and nature of formation of structure, phase composition, defect substructure and properties in surface layers of rail head along the central axis and along the fillet after different terms of operation is necessary for the production of premiumclass rails of increased wear resistance and low-temperature reliability including the differentially quenched ones.

In the home-produced bulk-strengthened rails with the passed tonnage of 500-1000 million tons, the formation of nanoscale multiphase structure in a metal layer adjacent to the working surface (fillet surface and tread surface) has been revealed. The structure is characterized by: the complete fracture of lamellar pearlite colonies (the surface layer); the proceeding of the initial stage of dynamic recrystallization of structure-free ferrite grains (the layer not less than $2 \mathrm{~mm}$ in thickness); the fragmentation of ferrite-carbide mixture grains with the formation of structure wherein the carbide phase particles are mostly located along subgrain boundaries [15-25].

Since 2013, the manufacture of 100-meter rails differentially quenched by pressed air in rolling mills has been started at JSC 'Evrazintegrated West Siberian metallurgical plant' in Russia. The certified batch of the rails is placed on experimental ring and the passed tonnage has been more than 1700 million tons gross weight.

For interim tests (passed tonnage of 691.8 million tons gross weight), the data bank on the regularities of formation of structural phase states and dislocation substructure, the distribution of carbon atoms in the head of long differentially quenched rails along central axis and along fillet after long-term operation was formed in researches [26-34]. The gradient character of structure, phase composition and defect substructure being characterized by the regular change in scalar and excess dislocation densities, the curvature-torsion of crystal lattice and the degree of strain transformation of lamellar pearlite structure along cross-section of rail head have been mentioned.

From the positions of physical materials science, the theoretical estimates of metal additive yield point along central axis and along fillet on the basis of multiaspect analysis of strengthening caused by carbide phase particles, by the formation of pearlite structure and dislocation substructure, by long-range stress fields and by solid-solution strengthening were performed in these researches. It was shown that irrespective of direction of the analysis and the distance to working surface the main contribution to strengthening was made by the dislocation substructure. It was determined that the change in the parameters of fine 
structure of ferrite constituent of pearlite colonies along central axis and along fillet had a gradient character.

The mode improvement of differential quenching of long rails for the formation of high operational properties should be based on the knowledge of mechanisms of structural phase changes along the crosssection of rails in their long operation. To reveal such mechanisms, it is possible only in the analysis of regularities of parameters' evolution of fine structure and the estimation of contributions of structural constituents and defect substructure to rail strengthening in long-term operation.

The goal of the current study is to establish the nature of strengthening, to reveal the regularities and to carry out a comparative analysis of structure, phase composition, defect substructure and properties being formed at different distances along central axis and along fillet in head of 100-meter differentially quenched rails after extremely long-term operation (with passed tonnage of 1411 million tons gross weight).

\section{Material and Methods of the Study}

The rails of DT350 category withdrawn from the track on Experimental ring of Russian railways after pass of 1411 million tons gross weight were used as material under study. The rails of certified batch were manufactured at OJSC 'Evraz-West Siberian Metallurgical Plant' in June 2013 according to the requirements of Technical Specifications 0921-276-01124323-2012 and were differentially thermo-strengthened. According to the chemical composition, the metal of rail sample meets the requirements (Table 1 ).

The metal macrostructure was detected by the method of deep etching in $50 \%$ hot water solution of hydrochloric acid on incomplete trans-

Table 1. Chemical composition of DT350 category rails

\begin{tabular}{|c|c|c|c|c|c|c|c|c|c|c|c|}
\hline \multirow{2}{*}{$\begin{array}{l}\text { Chemical } \\
\text { analysis }\end{array}$} & \multicolumn{11}{|c|}{ Content of chemical elements, $\%$} \\
\hline & $\mathrm{C}$ & $\mathrm{Mn}$ & $\mathrm{Si}$ & $\mathrm{P}$ & $\mathrm{S}$ & $\mathrm{Cr}$ & $\mathrm{Ni}$ & $\mathrm{Cu}$ & $\mathrm{V}$ & $\mathrm{Al}$ & $\mathrm{Ti}$ \\
\hline Testing & 0.72 & 0.77 & 0.61 & 0.010 & 0.009 & 0.42 & 0.07 & 0.14 & 0.038 & 0.003 & 0.003 \\
\hline Requirements & $0.71-$ & $0.75-$ & $0.25-$ & Not & more & 0.20 & $\Sigma$ no & more & $0.03-$ & Not 1 & more \\
\hline of Technical & 0.82 & 1.25 & 0.60 & & & 0.80 & 0.2 & $7 \%$ & 0.15 & & \\
\hline $\begin{array}{l}\text { Specification } \\
0921-276- \\
01124323- \\
2012 \text { for steel } \\
\text { of E76KhF } \\
\text { grade }\end{array}$ & & & & 0.02 & 0.02 & & 0.20 & 0.20 & & 0.004 & 0.025 \\
\hline
\end{tabular}


Fig. 1. Diagram of sample preparation by methods of transmission electron microscopy: 1 - tread surface, 2 - layer at $2 \mathrm{~mm}$ from surface, 3 - layer at $10 \mathrm{~mm}$ from surface; $a$ - fillet; $b$ - central axis

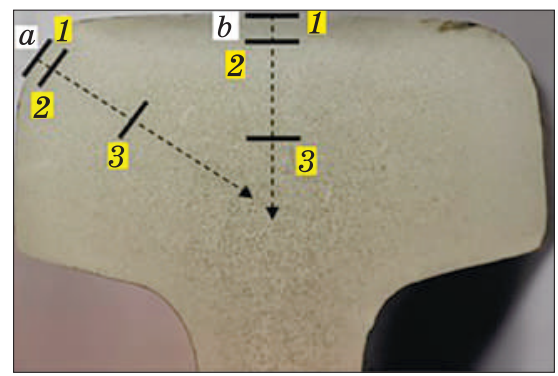

verse template (head, neck). The macrostructure estimation was performed in accordance with RD 14-2P-5-2004 'glossary of macrostructure defects of rails rolled from continuous-cast billets of electric steel'. The metal microstructure was studied on metallographic sections cut out from the upper part of head after etching in $4 \%$ alcoholic solution of nitric acid. The steel structure examinations were carried out using the methods of optical microscopy (metallographic microvisor $\mu$ VizoMET-221P), scanning electron microscopy (MIRA3 Tesan), x-ray structural analysis (x-ray diffractometer XRD-7000S (Shimadzu, Japan)) and transmission electron diffraction microscopy (device EM-125) [35-37]. The samples under test for transmission electron microscopy (150-200 nm thick foils) were manufactured by the methods of electrolytic thinning of plates cut out by the methods of electric spark erosion of metal and located near tread surfaces and fillet at a distance of 2 and $10 \mathrm{~mm}$ from the surface. The diagram of sample preparation is shown in Fig. 1.

The hardness measurement was performed by Brinell and Rockwell methods on tread surface in accordance with Technical Specifications TU 0921-276-01124323-2012. In addition, the hardness measurement in the upper part of the neck $(\approx 30 \mathrm{~mm}$ higher than point 6 of the requirements, article 1.8.1 TU 0921-276-01124323-2012) was done as well as along the cross-section of the neck in transverse direction at a distance of $2 \mathrm{~mm}, 10 \mathrm{~mm}$, and $22 \mathrm{~mm}$ from head tread surface along the vertical axis of symmetry. The microhardness was tested by the device PMT-3 by Vickers method at indenter load of $300 \mathrm{mN}$ at a distance of $2 \mathrm{~mm}$ and $10 \mathrm{~mm}$ from tread surface according to the results of 5 measurements in each zone.

\section{Results and Discussion}

\subsection{Structural-Phase State of Rails after Differential Quenching}

Differential quenching of steel is accompanied by the formation of morphologically multi-aspect structure presented by the grains of lamellar pearlite, ferrite-carbide mixture and structure-free ferrite being located as inclusions along the boundaries of pearlite grains (Fig. 2). 
The relative content of the detected types of structure depends on the depth of location of the layers under study (Table 2). When analysing the results given in this table, it may be noted that the relative volume fraction of structure-free ferrite grains $V(3)$ is small and varies in the limits from 0.01 and 0.05 of steel structure. The volume fraction of ferrite-carbide mixture $V(2)$ grains is substantially larger, whose value varies in the limits from 0.16 and 0.36 of steel structure and it decreases when moving away from rail head surface.

It is seen that, irrespective of the distance to rail head surface of fillet, the fraction of lamellar pearlite grains is lower, and the fraction of ferrite-carbide mixture grains is higher than on central axis, i.e., the processes of phase transformations having place at differential quenching along the central axis and fillet proceed by somewhat different thermo-kinetic diagrams.

The ferrite-carbide mixture grains are characterized by the presence of carbide phase particles being different in shape and sizes in ferrite volume. The globular-shape particles are also precipitated as short plates. When analysing TEM image of carbide phase particles being present in the bulk of ferrite-carbide mixture, it may be supposed that the grains with globular particles of cementite are the grains of globular pearlite; the grains with cementite particles in the form of short plates may be related to the grains of highly defective (degenerate) lamellar pearlite.

The dispersion of pearlite structure was estimated by the value of interlamellar distance (Fig. 3). It is seen that it varies in the limits from 125 to $185 \mathrm{~nm}$ and decreases at transition from tread surface deep into rail. Following to the Russian State Standard 8233-56, it may be said that the pearlite structure of all samples of rail steel under study is

Table 2. Relative content of structural constituents of DT350 rails

\begin{tabular}{|c|c|c|c|c|c|c|}
\hline \multirow{2}{*}{$\begin{array}{c}\text { Distance from } \\
\text { surface, mm }\end{array}$} & \multicolumn{3}{|c|}{ Along central axis } & \multicolumn{3}{c|}{ Along fillet } \\
\cline { 2 - 7 } & $V(1)$ & $V(2)$ & $V(3)$ & $V(1)$ & $V(2)$ & $V(3)$ \\
\hline 0 & 0.70 & 0.25 & 0.05 & 0.64 & 0.34 & 0.02 \\
2 & 0.84 & 0.16 & $<0.01$ & 0.61 & 0.36 & 0.03 \\
10 & 0.74 & 0.25 & $<0.01$ & 0.73 & 0.26 & $<0.01$ \\
\hline
\end{tabular}

Table 3. Scalar dislocation density of rail structural constituents

\begin{tabular}{|c|c|c|c|c|}
\hline \multirow{2}{*}{$\begin{array}{c}\text { Distance from } \\
\text { surface, } \mathrm{mm}\end{array}$} & \multicolumn{2}{|c|}{ Along central axis } & \multicolumn{2}{|c|}{ On fillet } \\
\cline { 2 - 5 } & $\rho(1), 10^{10}, \mathrm{~cm}^{-2}$ & $\rho(2), 10^{10}, \mathrm{~cm}^{-2}$ & $\rho(1), 10^{10}, \mathrm{~cm}^{-2}$ & $\rho(2), 10^{10}, \mathrm{~cm}^{-2}$ \\
\hline 0 & 4.6 & 5.6 & 4.5 & 6.0 \\
2 & 4.2 & 5.5 & 4.4 & 5.5 \\
10 & 4.0 & 5.0 & 4.1 & 5.0 \\
\hline
\end{tabular}



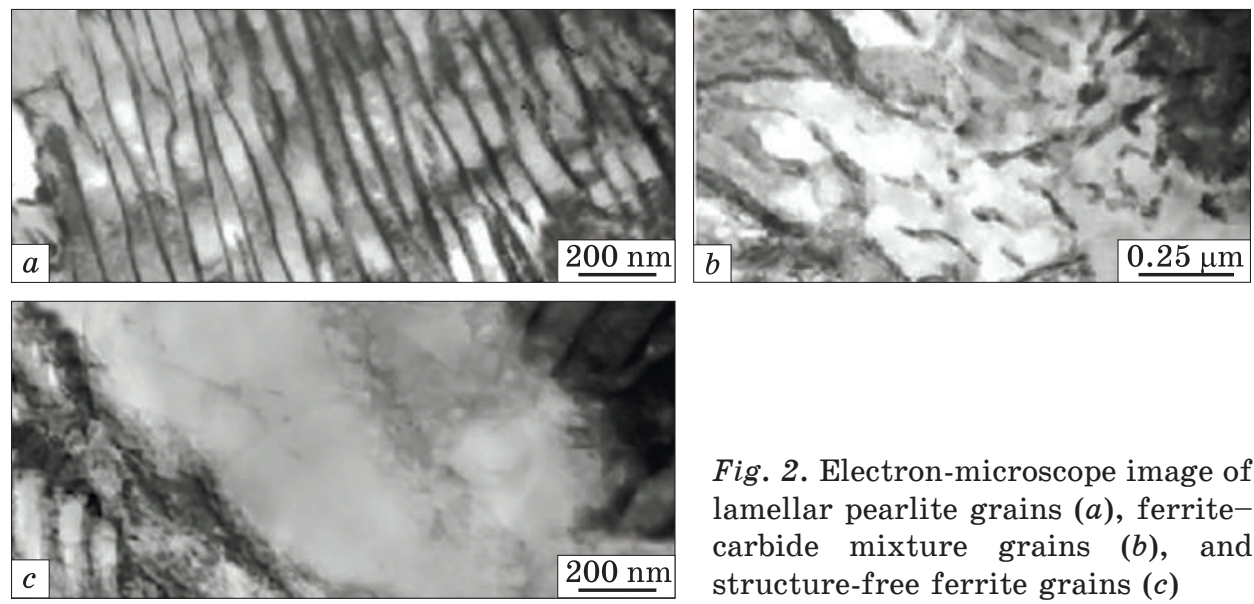

Fig. 2. Electron-microscope image of lamellar pearlite grains $(a)$, ferritecarbide mixture grains $(b)$, and structure-free ferrite grains $(c)$

related to the first number and is characterized as sorbitic one, a type of structure is troostite. The ferrite constituent of steel structure is imperfect. The dislocation substructure in the form of chaotically distributed dislocations, net-like, cellular and fragmentary dislocation substructures were detected by the methods of electron microscopy. In ferrite of pearlite grains, only the first two types of dislocation substructures (substructure of dislocation chaos and net-like dislocation substructure) are observed; the cellular and fragmentary dislocation substructures are detected only in the grains of structure-free ferrite and ferrite-carbide mixture.

The scalar dislocation density in steel under study varies in the limits from $4 \cdot 10^{10}$ to $6.0 \cdot 10^{10} \mathrm{~cm}^{-2}$. In this case, in ferrite-carbide mixture grains, the scalar dislocation density value is somewhat higher than in the ferrite constituent of pearlite grains independent of the location (along central axis or on fillet) and the distance of the layer under study on the tread surface (Table 3).

In the fillet surface layer up to $\approx 2 \mathrm{~mm}$ in thickness in ferrite of lamellar pearlite, the nanoscale $(<15 \mathrm{~nm})$ particles of carbide phase were revealed that indicates the repeated decay of solid solution based on $\alpha$-Fe after the formation

Fig. 3. Dependence of interlamellar distance of lamellar pearlite grains on distance from tread surface: 1 - analysis along central axis; 2 - along symmetry axis of fillet

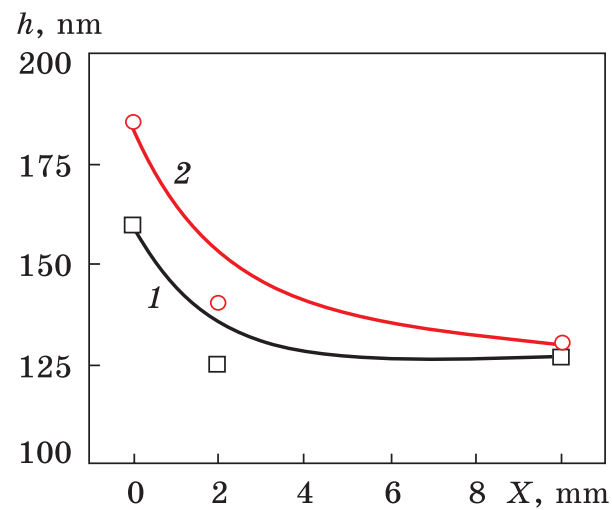



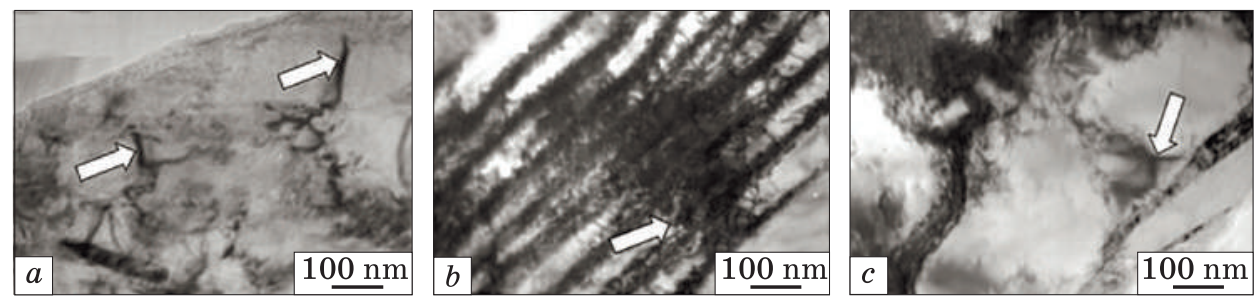

Fig. 4. Electron-microscope image of bend extinction contours (designated by arrows): $a$ - grains of ferrite-carbide mixture, $b-$ grains of lamellar perlite, $c-$ grains of structure-free ferrite

Table 4. Results of x-ray structural analysis of rails subjected to differential quenching

\begin{tabular}{|c|c|r|c|c|r|}
\hline \multirow{2}{*}{$\begin{array}{c}\text { Direction } \\
\text { of study }\end{array}$} & \multicolumn{2}{|c|}{ Phase composition, \% } & \multirow{2}{*}{$\alpha$-Fe, nm } & $\Delta d / d$ & $D_{\text {CSR }}, \mathrm{nm}$ \\
\cline { 2 - 3 } & $\mathrm{Fe}$ & $\mathrm{Fe}_{3} \mathrm{C}$ & & \\
\hline Axis & 90 & 10.0 & 0.28634 & 0.005 & 110.0 \\
Fillet & 93 & 7.0 & 0.28668 & 0.008 & 85.0 \\
\hline
\end{tabular}

of pearlite structure. As the similar nanoscale particles are not detected in the layer on central axis, it may be indicative of a higher cooling rate of the fillet.

The cementite plates of pearlite grains are defective; they are broken into fragments of $30-40 \mathrm{~nm}$ in size. The fragments' sizes are independent of the direction of study and the distance to rail head surface.

The electron-microscope studies of steel structure by the methods of thin foils in transmitted light permitted one to detect the bend extinction contours (Fig. 4). The presence of the bend extinction contours in material structure indicates the curvature-torsion of crystal lattice of the material volume in question and, consequently, the internal stress fields, bending a thin foil, and, therefore, strengthening the material.

The material hardening due to curvature-torsion of crystal lattice being exerted by internal stress fields is inversely proportional to the width of bend extinction contour [38, 39]. Therefore, having measured the contour width, one can estimate the relative value of material hardening introduced by internal stress fields. The average width of bend extinction contours being revealed in pearlite grains is $\approx 130 \mathrm{~nm}$, in structure-free ferrite $-90 \mathrm{~nm}$, in ferrite-carbide mixture grains $-80 \mathrm{~nm}$. The minimum width of bend extinction contours is detected near the carbide phase particles being present in ferrite-carbide mixture grains and amounts to $\approx 50 \mathrm{~nm}$. Consequently, the internal stress fields will reach the maximum values near the particles of the second phase. It means that carbide phase particles are the potential sites of microcracks 
formation (i.e., the stress concentrators) and may be dangerous in longterm operation of rails.

Analysing data on x-ray structural analysis of rail metal (Table 4), the difference in steel state along central axis and along symmetry axis of fillet may be noted. Along central axis (in relation to material bulk along fillet), the relative content of cementite is higher, $\alpha$-Fe lattice parameter is smaller, microstresses $(\Delta d / d)$ are lower, the sizes of coherent scattering region $\left(D_{\mathrm{CSR}}\right)$ are larger than in steel volume located on fillet. It indicates the higher cooling rate of the material volume located on fillet relative to the material located along central axis.

\subsection{Structural-Phase State and Properties of Metal along Central Axis of Rails after the Long-Term Operation}

It was determined by hardness measurements along cross-section of head in transverse direction that $H R C$ hardness at a depth of $2 \mathrm{~mm}$ is 37.1 , at $10 \mathrm{~mm}-35.8$, at $22 \mathrm{~mm}-35.6 \mathrm{HRC}$. The obtained results show that the hardness value at a depth of $2 \mathrm{~mm}$ in central zone is at a higher level (37.1 HRC) in comparison to metal hardness at a depth of $10 \mathrm{~mm}$ and $22 \mathrm{~mm}$ from the tread surface, that is evidently caused by the presence of material deep deformation in the indicated zone. Microhardness at a depth of $2 \mathrm{~mm}$ amounts to $1481 \mathrm{MPa}$; at a depth of $10 \mathrm{~mm}$, the microhardness value is substantially lower and amounts to $1210 \mathrm{MPa}$. It is obvious that the detected difference in microhardness values in metal thickness, as well as Rockwell hardness values given above, is caused by steel structural phase changes having place in rail operation.

On unetched metallographic sections prepared from head tread surface by the methods of optical microscopy, the single fine continuity violations to a depth of $30 \mu \mathrm{m}$ (Fig. 5, a) are revealed. The depth of deformation from tread surface is insignificant and is less than $35 \mu \mathrm{m}$ (Fig. 5, $b$ ).
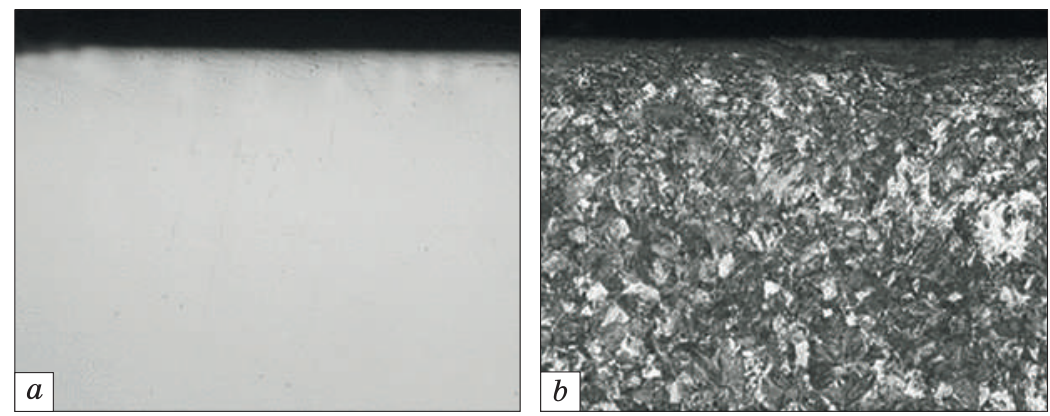

Fig. 5. Structure of rail tread surface: $a-$ unetched metallographic section; $b-$ etched metallographic section $(\times 200$ magnification $)$ 

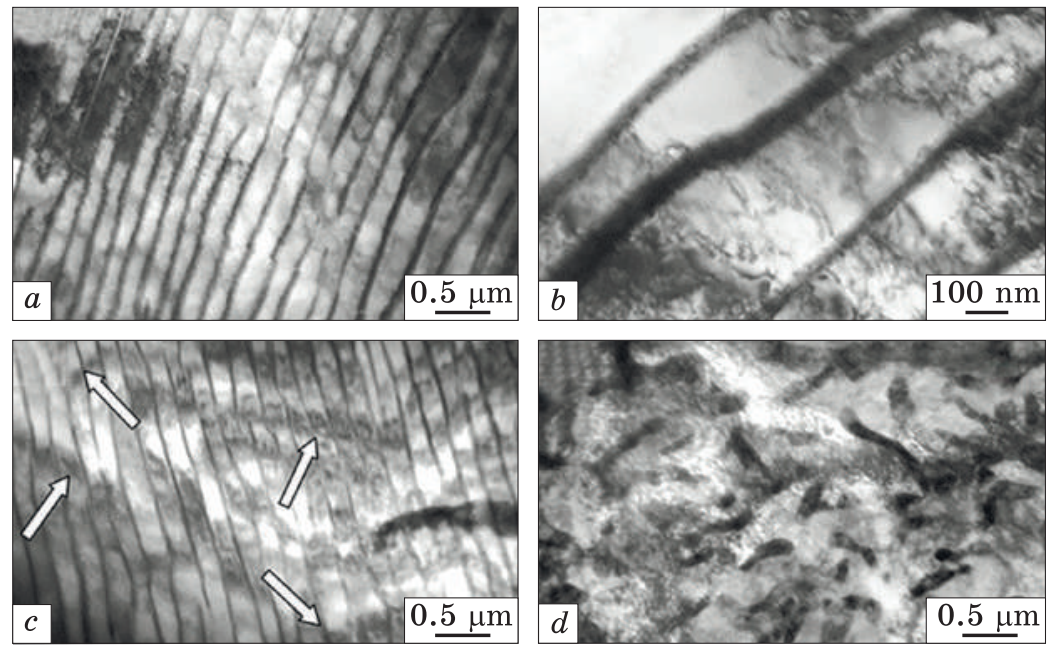

Fig. 6. Structure of rail metal in the layer located at a distance of $10 \mathrm{~mm}$ from tread surface

It was stated as a result of studies performed by the methods of transmission electron microscopy that the steel layer at a depth of $10 \mathrm{~mm}$ is presented mainly by pearlite of lamellar morphology whose characteristic image is shown in Fig. $6, a$. The cementite plates in pearlite colonies are curved and divided by ferrite bridges. The relative content of lamellar pearlite is $0.7 \%$ of steel structure. The dislocation substructure is revealed in ferrite constituent of pearlite colonies. The dislocations are located chaotically or form dislocation clusters (Fig. 6, $b$ ). The scalar dislocation density determined by random linear intercept methods is $\langle\rho\rangle=2.54 \cdot 10^{10} \mathrm{~cm}^{-2}$.

The bend extinction contours [38, 39] are observed on electron microscope images of pearlite colonies (Fig. 6, $c$, the contours are designated by arrows). The presence of such contours is indicative of curvature-torsion of material crystal lattice. Using the bend extinction contours, it is possible to perform the estimation of excess dislocation density leading to curvature-torsion of crystal lattice of foil part [4042] under study. The estimates made show that excess dislocation density in rail steel layer located at a distance of $10 \mathrm{~mm}$ from tread surface is $\rho=1.7 \cdot 10^{10} \mathrm{~cm}^{-2}$.

The colonies of degenerate pearlite wherein the cementite has a globular shape (Fig. 6, $d$ ) and the grains of structure-free ferrite $(0.05$ of steel structure) are detected in a substantially smaller quantity (0.25) in structure of steel layer under study.

The structure of layer located at a distance of $2 \mathrm{~mm}$ from tread surface is characterized by a number of peculiarities distinguishing it from the structure of the layer located at a depth of $10 \mathrm{~mm}$. To these 

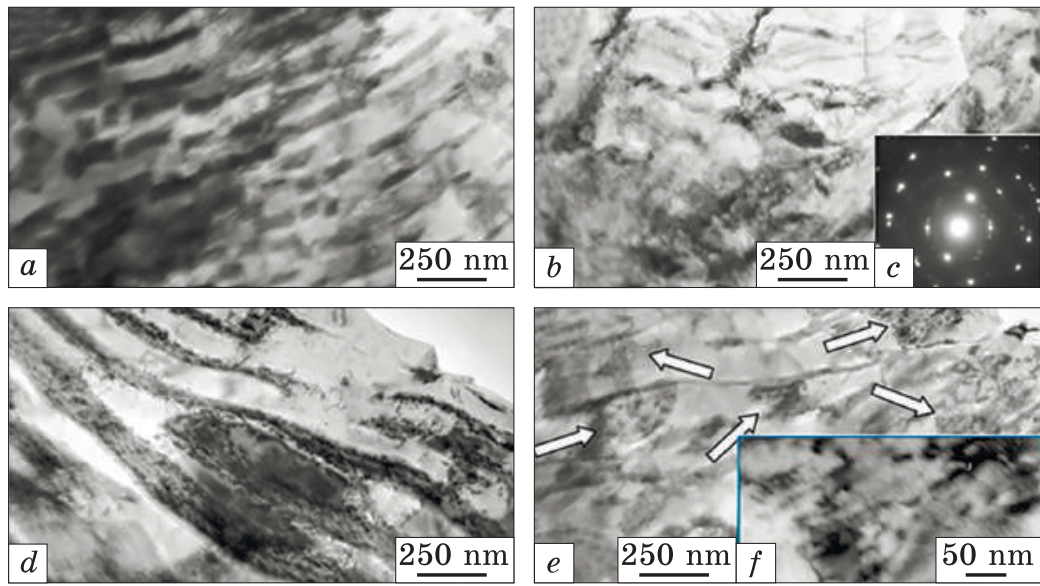

Fig. 7. Electron-microscope image of rail metal structure at a depth of $2 \mathrm{~mm}$. Arrows on $(e)$ indicate the ferrite areas with nanoscale cementite particles' precipitations
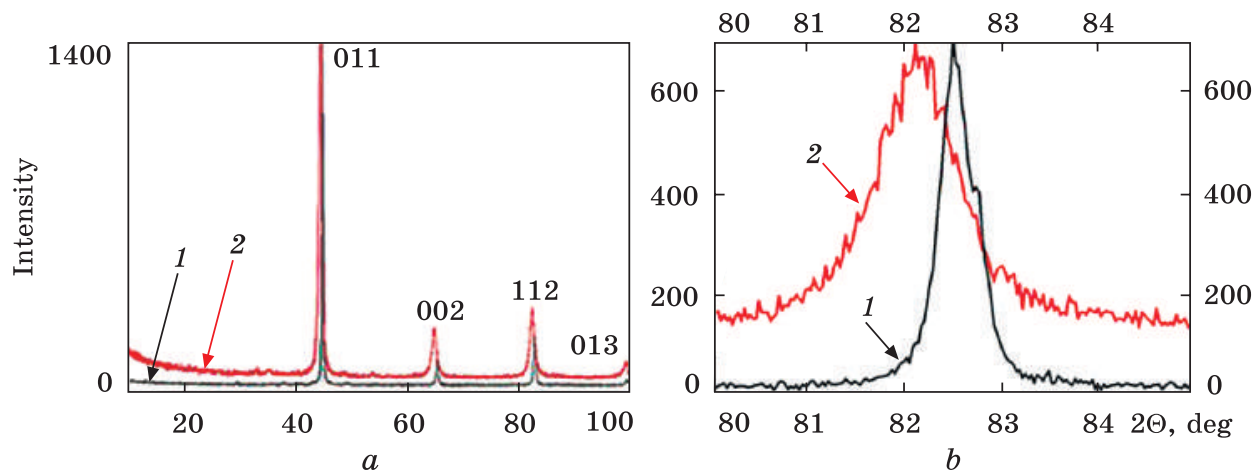

Fig. 8. Parts of x-ray diffraction patterns obtained from steel bulk located at a distance of $20 \mathrm{~mm}$ from tread surface (1) (hereinafter referred to as initial state) and from tread surface (2). Indexes of $\alpha$-phase diffraction lines are indicated on $(a)$; $\alpha-F e$ diffraction maximums [112] are shown on $(b)$

should be attributed the following: firstly, the lamellar pearlite, in whose volume of colonies the cementite plates are cut and displaced relative to each other (Fig. 7, a); secondly, the fragmentary (subgrain) structure being present in grains of degenerate pearlite (Fig. 7, b) (the presence of displacements on $\alpha$-phase reflections on microelectron diffraction patterns obtained from such a structure enables one to estimate the azimuthal component of angle of structural complete disorientation reaching $5^{\circ}$ ); thirdly, the fracture of cementite plates of lamellar pearlite by their dissolution with escape of carbon atoms to dislocations with subsequent precipitation in the form of nanoscale particles in the bulk of ferrite plates (Fig. 7, $d-f$ ). The cementite particles of round shape, 

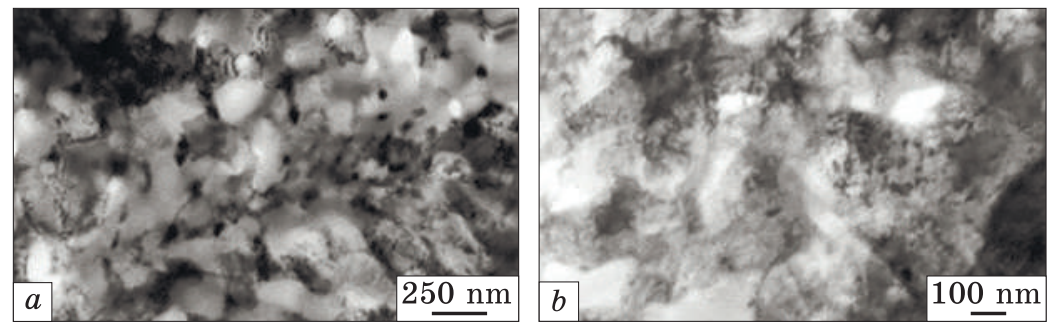

Fig. 9. Electron-microscope image of layer structure adjoining to tread surface

more seldom of lamellar shape, locate, as a rule, on dislocation lines, pinning them and forming a netlike dislocation substructure (Fig. 7, $e$, $f)$. It is evident that the variants of steel structure transformation, considered above, are a consequence of material deep plastic deformation.

The structural-phase state of the metal of rail tread surface was studied by the methods of $\mathrm{x}$-ray phase analysis and electron diffraction microscopy. The characteristic $\mathrm{x}$-ray diffraction patterns of the material under study are shown in Fig. 8.

The $\mathrm{x}$-ray phase analysis shows that the main phases of steel under study are $\alpha$-Fe-based solid solution (body-centred cubic crystal lattice) and iron carbide $\left(\mathrm{Fe}_{3} \mathrm{C}\right.$, cementite, orthorhombic crystal lattice). The $\alpha-F e$ crystal lattice parameter in the initial state is $a_{\text {init }}=0.28693 \mathrm{~nm}$; that of tread surface $-a_{\text {t.s. }}=0.28699 \mathrm{~nm}$. Supposing that the increase in $\alpha-F e$ crystal lattice parameter is connected with cementite dissolution and the escape of carbon atoms into solid solution, let us estimate a carbon concentration in $\alpha-\mathrm{Fe}$-based solid solution using the relations offered in [43]. The performed estimates show that the detected increase in $\alpha-\mathrm{Fe}$ crystal lattice parameter may correspond to the transition of 0.0015 wt. $\%$ carbon to solid solution. Simultaneously with the increase in crystal lattice parameter, a substantial broadening of diffraction lines (Fig. 8, b) is observed. The diffraction line broadening may be caused by small size of scattering crystallites and significant microdistortions (stresses of the second sort) in crystallites. Therefore, the analysis of diffraction-peaks' shape, their displacements and broadenings is used for the determination of average size of coherent scattering regions (CSR) and microdeformation value [40]. However, it should be considered that, if CSR $(D)$ size is large and/or the value of crystal lattice microdistortions $(\varepsilon)$ is small, it is impossible to calculate the given characteristics of a material. Therefore, there are a minimum value $D$ and maximum value $\varepsilon$, which may be determined from the line broadenings: $0.005 \mu \mathrm{m}<D<0.2 \mu \mathrm{m}$ and $10^{-4}<\varepsilon<10^{-2}$. The analysis of diffraction patterns performed in the research has shown that, for initial-state steel, we fail to determine the values of sizes of coherent-scattering re- 
gions $D_{\text {init. }}$ and microdistortions' values $(\Delta d / d)_{\text {init. }}$. It may mean that $D_{\text {init. }}>0.2 \mu \mathrm{m}$ and $(\Delta d / d)_{\text {init. }}<10^{-4}$. For the tread surface, the values were determined, and they amount to $D=22.06 \mathrm{~nm}, \Delta d / d=1.562 \cdot 10^{-3}$. Thus, after the passed tonnage of 1411 million tons gross weight, the tread surface metal is characterized by a small value of coherent scattering regions and comparatively large magnitudes of $\alpha$-phase crystallattice microdistortions.

A characteristic electron-microscope image of metal layer structure forming the tread surface is displayed in Fig. 9. It is clearly seen that the result of extremely long operation of rails is a substantial transformation of pearlite structure. Along with the colonies having retained the morphology of lamellar pearlite, a structure of subgrain type whose relative content is 0.55 of steel structure (Fig. 9, $a$ ) is formed in surface layer. The subgrains' sizes vary in the limits from $100 \mathrm{~nm}$ to $150 \mathrm{~nm}$. Along with the subgrain boundaries and in boundary junctions, the carbide phase particles, whose sizes vary in the limits from $30 \mathrm{~nm}$ to $55 \mathrm{~nm}$, are located. Rather often, the second phase particles are located in bulk of subgrains on dislocation lines (Fig. 9, b). The dimensions of the particles vary in the limits from $10 \mathrm{~nm}$ to $15 \mathrm{~nm}$. The scalar dislocation density in pearlite colonies' structure is $\langle\rho\rangle=3.7 \cdot 10^{10} \mathrm{~cm}^{-2}$; in subgrain structure, $\langle\rho\rangle=3.0 \cdot 10^{10} \mathrm{~cm}^{-2}$. Comparing the results mentioned above, it might be noted that scalar dislocation density value of the surface layer increases 1.5-fold that of the layer located at a depth of $10 \mathrm{~mm}$. The excess dislocation density increases similarly (1.5-fold) in the layer forming the tread surface.

\subsection{Structural and Phase States of Metal along Symmetry Axis of Rail 'Working' Fillet after Operation}

It has been established that rail structure is formed by pearlite grains of lamellar morphology (Fig. 10, $a$ ) in the layer located at a distance of $10 \mathrm{~mm}$ from fillet surface. The regions of 'degenerate pearlite' (Fig. 10, b) and the grains of structure-free ferrite (the ferrite grains, in whose volume the cementite particles are absent) (Fig. 10, c) are present in a minimum quantity.

At a distance of $2.0 \mathrm{~mm}$ from working fillet surface, a deformed pearlite containing the cementite plates fractured into separate particles and displaced relative to each other (Fig. 11, $a$ ) is added to the steel structural constituents mentioned above. In fillet surface layer, the structure of 'ferrite-carbide mixture' (Fig. 11, b) is formed in addition to those stated above.

The characteristic feature of the structure is a nanoscale range of grains, subgrains and carbide phase particles (Fig. 12) forming it. The size of grains and subgrains forming the type of structure varies in the 

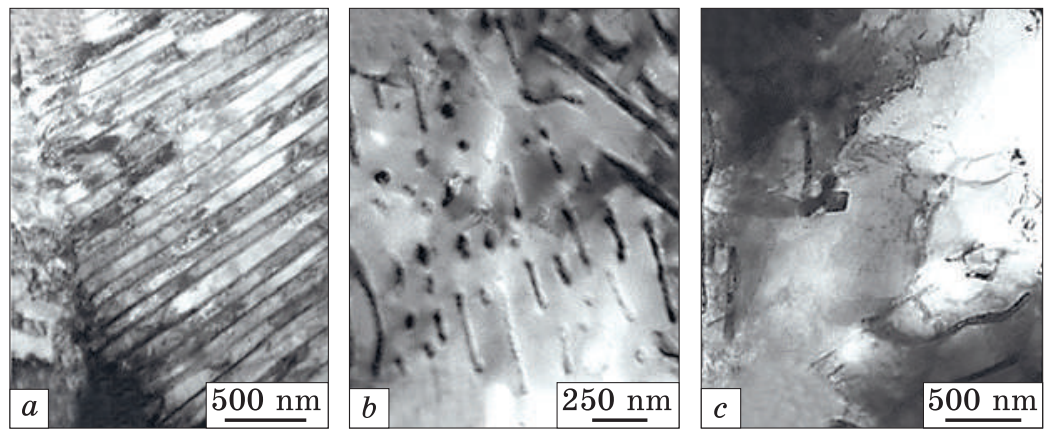

Fig. 10. Electron-microscope image of rail metal structure in the layer at a depth of $10 \mathrm{~mm}$ : $a$ - lamellar pearlite; $b$ - degenerate pearlite; $c$ - structure-free ferrite
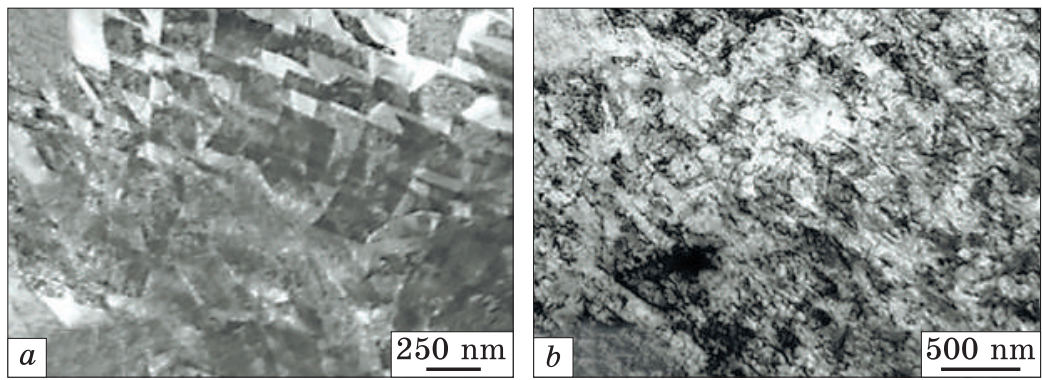

Fig. 11. Structure of rails' metal, where $a$ - lamellar fractured pearlite, and $b$ - ferrite-carbide mixture. Here, $a$ - layer at a depth of $2 \mathrm{~mm}$, while $b$ - surface layer of working fillet metal
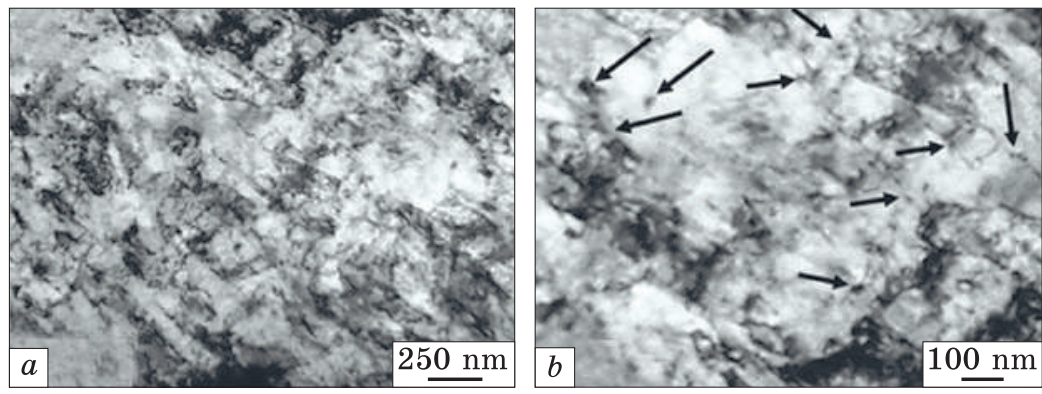

Fig. 12. Electron-microscope image of 'ferrite-carbide mixture' structure. Arrows (b) indicate particles of carbide phase

limits of $40-70 \mathrm{~nm}$ (Fig. 12, a). The size of carbide phase particles located along the boundaries of grains and subgrains varies in the limits of 8-20 nm (Fig. 12, b).

The relative content of structural constituents of rail metal shown in Figs. 10 and 11 varies according to Fig. 13. 
Fig. 13. Diagram of relative content of rail structural constituents: 1 degenerate perlite + fractured pearlite; 2 - lamellar pearlite; 3 - ferrite-carbide mixture

It is clearly seen that rail long-term operation is accompanied by the formation of structural constituents' gradient consisting in the regular decrease

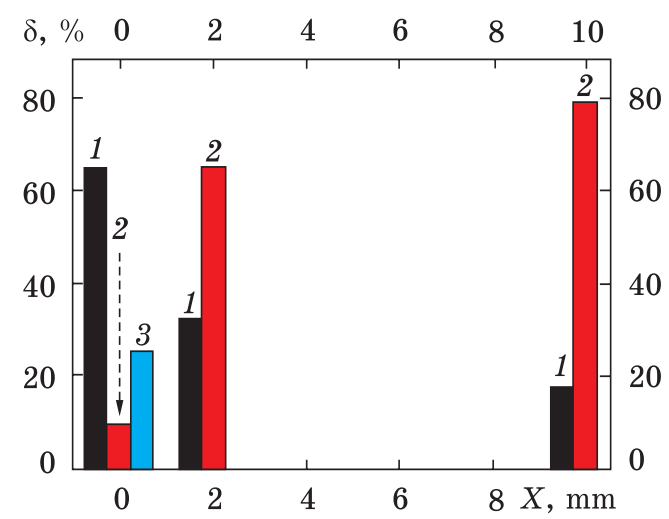
in relative content of material volume with lamellar pearlite structure and the increase in that with the structure of fractured pearlite and ferrite-carbide mixture as the fillet surface is approached.

It is stated by the methods of transmission electron microscopy that the dislocation substructure (Fig. 14,a) is present in the ferrite constituent of pearlite colonies and the grains of structure-free ferrite. Following the classification given in [39, 42], the dislocations form tangles and networks or are distributed chaotically. The results presented in Fig. 14, $b$ testify that scalar dislocation density of rails increases as fillet surface is approached. Scalar dislocation density increases the most intensively in lamellar pearlite structure, the least intensively in the structure of degenerate pearlite and fractured pearlite.

The long-term operation of rails is accompanied by the formation of internal stress fields in steel. In studying the steel structure by the methods of transmission electron microscopy, the presence of stress

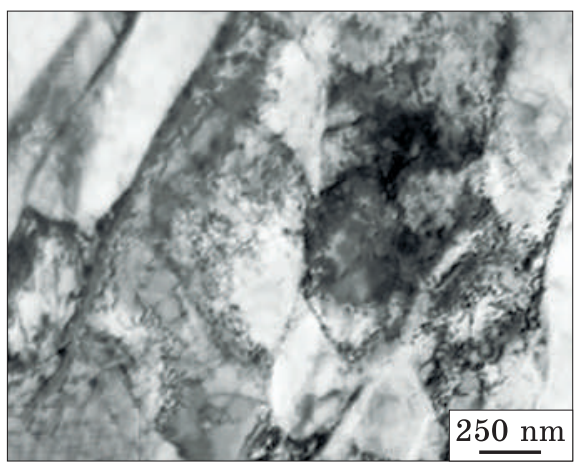

$a$

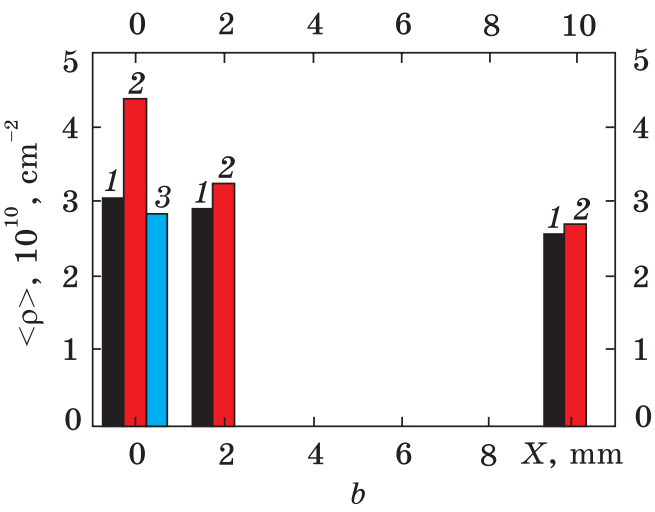

Fig. 14. The rail dislocation substructure observed in the layer at a depth of $10 \mathrm{~mm}$ from fillet surface $(a)$, and diagram of scalar dislocation density gradient $(b)$, where $X$ is a distance from the working fillet surface; 1 - degenerate pearlite + fractured pearlite; 2 - lamellar pearlite; 3 - ferrite-carbide mixture 


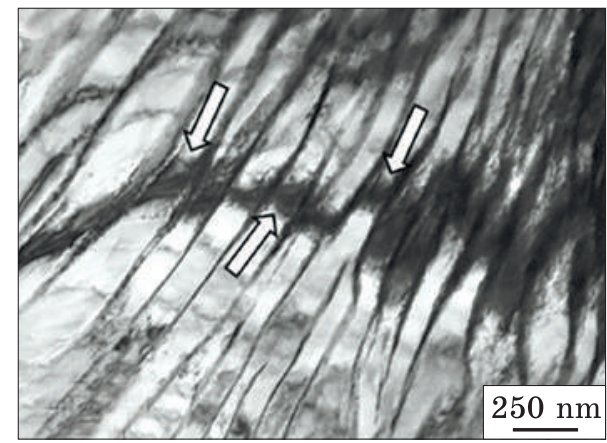

$a$

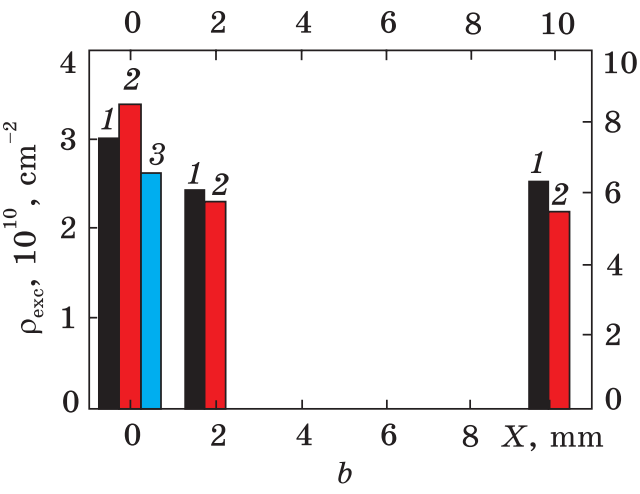

Fig. 15. Electron-microscope image of rail structure in the layer located at a distance of $10 \mathrm{~mm}$ from fillet surface $(a)$, and diagram of excess dislocation density gradient $(b)$, where $X$ - distance from working fillet surface; 1 - degenerate pearlite + fractured pearlite; 2 - lamellar pearlite; 3 - ferrite-carbide mixture. Bend extinction contour is designated by arrows $(a)$
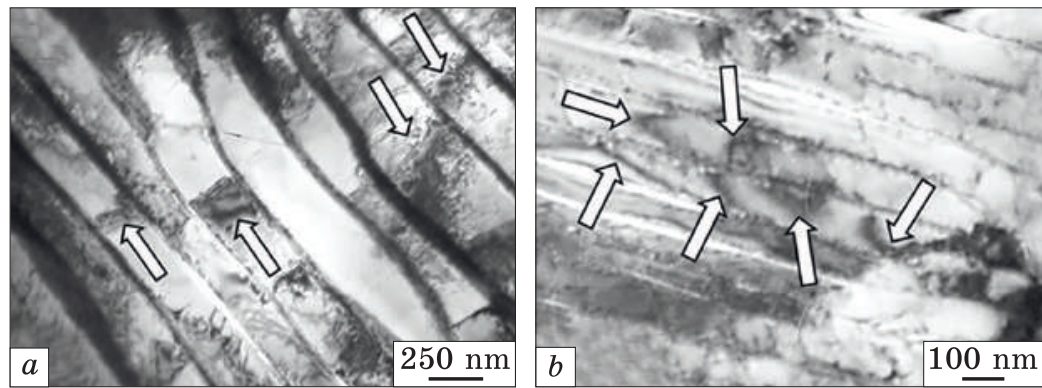

Fig. 16. Electron-microscope image of extinction contours (designated by arrows)

fields in the material is exhibited in the appearance of bend extinction contours [44] indicative of curvature-torsion of crystal lattice of the foil part (Fig. 15, a) on electron-microscope images.

The bending of crystal lattice in metals and alloys including steel (curvature-torsion of crystal lattice) may be of several types [45, 46]: firstly, a pure elastic bending being created by stress fields accumulated due to incompatibility of deformation, for example, grains of polycrystals, colonies of lamellar pearlite, or plastic material with undeformed particles (the sources of stress fields arising largely under material inhomogeneous deformation, in this case, are boundary junctions and boundaries of polycrystals' grains, disperse undeformed particle/matrix interfaces, in some cases, cracks); secondly, plastic bending, if a bending is produced by dislocation charges i.e., excess dislocation density localized in a certain bulk of a material; thirdly, elastoplastic bending, when both sources of fields are present in a material. 
Analysis procedure of internal stress fields based on behaviour of bend extinction contours at tilt of foil in microscope column was firstly developed and tested on different materials in Refs. [41, 46]. The estimation procedure of internal stress fields' value is reduced to the determination of curvature-torsion of crystal lattice, $\chi$ :

$$
\chi=\frac{\partial \phi}{\partial \ell}=\frac{0.017}{h},
$$

where $h$ is a transverse size of bend extinction contour.

The value of excess dislocation density $\rho_{ \pm}$is connected with curvature-torsion gradient of crystal lattice $\chi$ through absolute value of the Burgers dislocation vector $b$ :

$$
\rho_{ \pm}=\frac{1}{b} \frac{\partial \phi}{\partial \ell} .
$$

Thus, having determined experimentally the transverse sizes of bend extinction contour of various structural constituent of steel, it is possible to estimate the value of excess dislocation density.

Analysing results in Fig. 15, $b$, it may be noted that excess dislocation density value reaches the largest magnitudes in lamellar pearlite structure, the least ones - in ferrite-carbide mixture structure. As the distance from fillet surface increases, the value of excess dislocation density decreases that testifies to the decrease in amplitude of internal stress fields of rail metal.

As established, the scale of localization of internal stress fields of rail material depends, in a regular way, on the distance from fillet surface. It is detected that, in steel layer located at a depth of $\approx 10 \mathrm{~mm}$, the internal stress fields are localized in bulk of pearlite colony, the sources of stress fields are the interfaces of colonies or pearlite grains (Fig. 15, a). In the layer located at a distance of $\approx 2 \mathrm{~mm}$ from fillet surface, the extinction contours are localized in bulk of several ferrite plates (Fig. 16, $a$ ). In the layer forming the fillet surface, the extinction contours are localized mainly in bulk of individual ferrite plates (Fig. 16, b). It means that deformation effect having place in long-term operation of rails results in formation of gradient of localization volume of internal stress fields of rail metal and, consequently, a substantial increase in number of stress concentration that, in its turn, will facilitate the increase in level of embrittlement and rails' failure.

\subsection{Physical Nature of Rail Metal Strengthening in the Long-Term Operation}

The results mentioned above show that rail metal microhardness after long-term operation depends essentially on the distance to the tread surface, viz., at a depth of $2 \mathrm{~mm}$, it amounts to $1480 \mathrm{MPa}$; at a depth of $10 \mathrm{~mm}$, it is lower and amounts to $1210 \mathrm{MPa}$. It is obvious that the 
detected difference in microhardness values in metal thickness is due to structure phase changes of steel having place in rail operation. The results of the analysis of steel structure and phase composition presented above are indicative of a multi-aspect strengthening of the material. The obtained quantitative characteristics enable one to examine a physical nature of steel strength, to carry out the estimate of mechanisms of its strengthening and to find the dominant mechanisms determining the steel strength being characterized by microhardness in the research. It is evident that in determining the material microhardness, it is impossible to take into account all morphology and phase diversity of steel structure. In this context, let us realize the quantitative estimate of steel strengthening mechanisms relying on the averaged in material volume (with regard to volume fraction and characteristics of substructure types) qualitative characteristics. The estimates of strengthening mechanisms value were performed using widely tested expressions given below.

The value of steel yield strength caused by the formation of lamellar pearlite may be estimated according to the expression [47, 48]:

$$
\sigma(P)=k_{y} \cdot 1 / \sqrt{4.75 L} \cdot 0.24 V(P),
$$

where $L-$ distance between cementite plates, $V(P)$ - relative content of lamellar pearlite in steel, $k_{y}=2 \cdot 10^{-2} \mathrm{~Pa} \cdot \mathrm{m}^{1 / 2}$.

The stress required for maintaining the plastic deformation, i.e. the flow stress $\sigma$ needed for overcoming the interaction forces with immobile dislocations ('forest' dislocations) by moving dislocations (deformation carriers) is connected with scalar dislocation density by the following relation [47-49]:

$$
\sigma_{\mathrm{d}}=\sigma_{0}+\alpha m G b \sqrt{\langle\rho\rangle},
$$

where $\sigma_{0}-$ flow stress of nondislocation origin (i.e. caused by other strengthening mechanisms); $\langle\rho\rangle-$ average (scalar) dislocation density; $m$ - Schmidt orientation factor; $\alpha-$ parameter characterizing the value of interdislocation interactions being equal to $0.1-0.51[50,51]$; $G$ - shear modulus of steel $(\approx 80 \mathrm{GPa}) ; b-$ absolute value of the Burgers dislocation vector $(0.25 \mathrm{~nm})$. For steels with regard to orientation factor, $m$ is commonly assumes as $m \alpha \approx 0.5$.

The value of plastic constituent of internal stress fields may be estimated based on the relation $[40,41,46,52,53]$ :

$$
\sigma_{\text {pl. }}=m \alpha G b \sqrt{\rho_{ \pm}} \text {. }
$$

The value of elastic constituent of internal stress fields is estimated based on the relation $[46,52,53]$ :

$$
\sigma_{\text {elast. }}=m \alpha G t \chi_{\text {упр }},
$$

where $t-$ foil thickness taken in calculation being equal to $200 \mathrm{~nm}$; $\chi_{\text {elast. }}-$ elastic constituent of curvature-torsion of crystal lattice. The 
value of excess dislocation density $p_{ \pm}$relates to the crystal lattice curvature-torsion gradient $\chi$ through Burgers dislocation vector magnitude $b$ by the relation (2).

The rails' operation is accompanied by the process of steel dynamic ageing that results in the formation of nanoscale particles of iron carbide in the material. The iron carbide particles whose sizes exceed $5 \mathrm{~nm}$ lose the coherent bond with $\alpha$-phase crystal lattice [47, 54]. Therefore, the nanoscale particles of carbide phase whose sizes exceed $10 \mathrm{~nm}$ being present in rail steel are incoherent. The incoherent cementite particles are an obstacle to dislocation motion that results in material strengthening. The estimations of steel strengthening taking into account the presence of incoherent particles of the second phase are performed using the relation [55]:

$$
\sigma_{\text {part. }}=M \frac{m G_{m} b}{2 \pi(|\lambda-D|)} \Phi \ln \left|\frac{\lambda-D}{4 b}\right|,
$$

where $\lambda$ - average distance between particles; $D$ - average size of particles; $m$ - orientation factor being equal to 2.75 for b.c.c.-lattice-based materials; $\Phi=1$ for screw dislocations, and $\Phi=(1-v)^{-1}$ for edge dislocations; $M$ - parameter considering the nonuniformity of particle distribution in matrix being equal to $0.81-0.85$ [51].

The rail operation is accompanied by the formation of fragmentary substructure in surface layer. The material strengthening by low angle boundaries (substructural strengthening, strengthening by fragments' boundaries) dividing the fragments may be estimated using the relation $[1,4,47]$ :

$$
\sigma(L)=\sigma_{0}+k^{*} L^{-m},
$$

where $m=1$ or $1 / 2 ; L-$ mean size of fragment. If $m=1, k^{*}$ varies as $150-100 \mathrm{~N} / \mathrm{m}$; if $m=1 / 2, k^{*}$ varies from $2 \cdot 10^{-3}$ to $10^{-2} \mathrm{~Pa} \cdot \mathrm{m}^{1 / 2}[47$, $54,56]$.

In the calculations, the following parameter values appearing in the last equation were used: $k^{*}=150$ and $m=1$. The $\sigma_{0}$ is a friction stress of material crystal lattice, i.e., the stress required for dislocation motion in one-phase 'pure' monocrystals (the monocrystals do not contain impurities). The stress $\sigma_{0}$ depends essentially on the degree of material purity and the value of its imperfection. For theoretically pure material, $\sigma_{0}=17 \mathrm{MPa}$. The experimentally determined values of $\sigma_{0}$ vary in the limits from 27 to $60 \mathrm{MPa}[47,50]$. The value $\sigma_{0}$ being equal to $30-40 \mathrm{MPa}$ [47] is usually used for steels.

The rail operation is accompanied by dissolution (fracture) of cementite as it was shown above. In this case, carbon being liberated takes part in the formation of nanoscale particles of secondary cementite, precipitates on structure defects and gets into interstitial sites of steel crystal lattice. The estimation of steel solid solution strengthening caused by 
carbon atoms was performed using the empirical expression [47, 56]:

$$
\sigma_{\text {sol.sol. }}=\sum_{i=1}^{m}\left(k_{i} C_{i}\right) \text {, }
$$

where $k_{i}$ - coefficient of ferrite strengthening representing the material strength increment at yield point on dissolving of $1 \mathrm{wt} . \%$ alloying element in it; $C_{i}$ - concentration of element dissolved in ferrite [wt.\% ]. The value of $k_{i}$ coefficient for different elements is determined empirically $[57,58]$.

The total yield point of steel in a first approximation based on additivity principle that assumes the independent action of each of material strengthening mechanisms may be represented in the form of linear sum of contributions of individual strengthening mechanisms [46-48, $52,56,59,60]:$

$$
\sigma=\Delta \sigma_{0}+\Delta \sigma(L)+\Delta \sigma(\rho)+\Delta \sigma(h)+\Delta \sigma_{\text {part. }}+\Delta \sigma_{\text {sol.sol. }}+\Delta \sigma(P),
$$

where $\Delta \sigma_{0}=30 \mathrm{MPa}$ - contribution due to matrix lattice friction; $\Delta \sigma(L)-$ contribution due to interphase boundaries; $\Delta \sigma(P)-$ contribution due to dislocation substructure; $\Delta \sigma(h)$ - contribution due to internal stress fields; $\Delta \sigma_{\text {part. }}-$ contribution due to the presence of carbide phase particles; $\Delta \sigma_{\text {sol.sol. }}$ - contribution due to solid solution strengthening; $\Delta \sigma(P)-$ contribution due to pearlite constituent of steel structure.

Thus, having determined the quantitative characteristics of steel structure, it is possible in a first approximation to analyse the physical mechanisms responsible for steel hardness evolution in the process of rail operation as well as to detect the physical mechanisms of formation of rail steel hardness gradient.

Table 5. Estimations of rail metal strengthening mechanisms being formed at different distance along the central axis and along the fillet in head of 100-meter differentially quenched rails after extremely long-term operation (passed tonnage of 1411 million tons gross weight)

\begin{tabular}{|l|c|c|c|c|c|c|}
\hline \multirow{2}{*}{$\begin{array}{c}\text { Parameters } \\
\text { average } \\
\text { in material, } \\
\mathrm{MPa}\end{array}$} & \multicolumn{3}{|c|}{ Tread surface } & \multicolumn{3}{c|}{ Working fillet } \\
\cline { 2 - 7 } & $10 \mathrm{~mm}$ & $2 \mathrm{~mm}$ & Surface & $10 \mathrm{~mm}$ & $2 \mathrm{~mm}$ & Surface \\
\hline$\Delta \sigma(P)$ & 142.5 & 161.5 & 85.5 & 152 & 152 & 95 \\
$\Delta \sigma(L)$ & 0 & 0 & 473.3 & 0 & 0 & 1455.6 \\
$\Delta \sigma(\rho)$ & 152.8 & 181 & 181.4 & 164 & 206 & 190.4 \\
$\Delta \sigma(h)$ & 131.3 & 149 & 255 & 148.6 & 149.6 & 230.4 \\
$\Delta \sigma_{\text {part. }}$ & 154.1 & 148.5 & 107 & 80.6 & 222.9 & 195 \\
$\Delta \sigma_{\text {sol.sol. }}$ & 11 & 11 & 11.7 & 11 & 11 & 11.7 \\
$\sigma=\sum_{i=1}^{n} \sigma_{i}$ & 591.7 & 651 & 1114 & 556.2 & 741.5 & 2178.1 \\
\hline
\end{tabular}


Using the results of quantitative analysis of steel structure considered above, the estimations of steel strengthening mechanisms were carried out. The results of estimations are listed in Table 5.

Analysing results in Table 5, the following may be noted. Firstly, steel strength is a multiaspect value and is determined by the combined action of a number of physical mechanisms. Secondly, rail metal strength depends on the distance to rail head surface independent of the place of the analysis (along the central axis or along symmetry axis of fillet) that is in agreement with the results obtained in determination of steel microhardness. Thirdly, rail metal strength increases as rail head surface is approached. Fourthly, the main mechanism of rail metal strengthening in a subsurface layer (the layer located at a depth of 2 and $10 \mathrm{~mm}$ ) or rail head is the dislocation one caused by the interaction of moving dislocations with immobile ones ('forest' dislocations). In the fifth place, in surface layer of rail head, the main mechanism of metal strengthening is substructural mechanism due to the interaction of mobile dislocation with low angle boundaries of fragments and subgrains of nanometer size.

\section{Conclusion}

The layer-by-layer study and analysis of structural phase states, defect substructure and properties of differentially quenched 100-meter rails of DT350 category in the initial state and after passed tonnage of 1411 million tons gross weight were carried out by the methods of physical material science. It has been established that independent of the distance to the rail head surface and direction of study (along the central axis or along the fillet), the quenching is accompanied by the formation of morphologically multiaspect structure presented by lamellar pearlite grains, ferrite-carbide mixture grains, and grains of structure-free ferrite being located as inclusions along pearlite grain boundaries. The quantitative analysis has been carried out and the main parameters characterizing the steel structure state have been detected. It has been shown that the structure being formed has a clearly defined gradient character, i.e., the surface layer state of rail steel under study depends on the direction of study (along the central axis and along the fillet) and depth of location of the layer being analysed. The fact of the decrease in relative content of structure-free ferrite grains and ferrite-carbide mixture grains with the increase in distance to the surface has been identified. The rail surface layer is characterized by a more nonequilibrium state of structure that is evidently caused by the increased rate of its cooling.

The analysis of evolution of structural phase state and properties along the central axis of rail head after long-term operation enabled us to determine that metal hardness of differentially quenched rails after 
passed tonnage of 1411 million tons at the depths of 2,10 , and $22 \mathrm{~mm}$ equals to $37.1,35.8$, and $35.6 \mathrm{HRC}$, respectively. It was suggested that perhaps the increase in hardness was due to the deep deformation of rail surface layer material in the operation process. Analysing the transverse microsections, the single small continuity violations up to $30 \mu \mathrm{m}$ in depth have been detected. It has been shown that deformation depth from tread surface being identified by the methods of etched microsection metallography is insignificant and is less than $35 \mu \mathrm{m}$. The extremely longterm operation of rails is accompanied by numerous transformations of metal structure of rail tread surface: firstly, by the fracture of lamellar pearlite structure and the formation of subgrain structure of submicron $(100-150 \mathrm{~nm})$ sizes in bulk of pearlite colonies; secondly, by the precipitation of carbide phase particles of nanoscale range along boundaries and in bulk of subgrains; thirdly, by the increase in microdistortions and crystal lattice parameter of $\alpha$-Fe-based solid solution; fourth, by the deformation strengthening of metal leading to 1.5 -fold increase (relative to the initial state) in scalar and excess dislocation densities.

It has been established that the rail structure after a long-term operation is formed by pearlite grains of lamellar morphology in the layer located at a distance of $10 \mathrm{~mm}$ from fillet surface. The regions of 'degenerate pearlite' and grains of structure-free ferrite (the ferrite grains in bulk of which cementite particles are absent) are present in negligible quantity. As shown, the long-term operation of rails is accompanied by the formation of structural constituents' gradient consisting in the regular change in relative content of lamellar pearlite, fractured pearlite and ferrite-carbide mixture structure along the cross-section of rail head. As the rail fillet surface is approached, the relative content of metal bulk with lamellar pearlite structure decreases and that with the structure of fractured pearlite and ferrite-carbide mixture structure increases. The characteristic feature of ferrite-carbide mixture structure is a nanoscale range of grains, subgrains and carbide phase particles forming it; the size of grains and subgrains forming the type of structure varies in the limits of $40-70 \mathrm{~nm}$; the size of carbide phase particles located along grain and subgrains boundaries varies in the limits of $8-20 \mathrm{~nm}$. It has been revealed that the long-term operation of rails is accompanied by the formation of material defect substructure gradient involving the regular increase in scalar and excess dislocation density. It has been determined that the scale of localization of rail internal stress fields depends, in a regular way, on the distance from fillet surface varying from bulk of pearlite colonies as a whole at a depth of $\approx 10 \mathrm{~mm}$ to bulk of single ferrite plates in fillet surface layer. It means that deformation effect having place in rail operation results in a substantial increase in number of stress concentrators that, in its turn, contributes to metal embrittlement. 
The analysis of strengthening mechanisms of rail head metal along symmetry axis of fillet and along the central axis (tread surface) has been carried out. As shown, in both cases, the strengthening has a multifactor character and is determined by superposition of several physical mechanisms.

It is shown that the increase hardness of rail steel subjected to extra-long-term operation has a multiaspect character and is caused by: firstly, the substructural strengthening due to the formation of nanoscale fragments whose boundaries are stabilized by carbide phase particles; secondly, the strengthening with carbide phase nanoscale particles located in bulk of fragments and on dislocations (dispersion strengthening); thirdly, the strengthening introduced by internal stress fields being formed due to deformation incompatibility of adjacent grains, crystallites of different phases, presence of microcracks.

It is established that the most significant physical mechanisms ensuring the high strength properties of rail head metal subjected to extremely long-term operation are: the dislocation mechanism caused by interaction of moving dislocations with immobile dislocations ('forest' dislocations) in a subsurface layer (the layer located at a depth of 2$10 \mathrm{~mm}$ ) of rail head and substructural mechanism (surface layer) due to the interaction of mobile dislocation with low angle boundaries of fragments and subgrains of nanometer size.

Acknowledgements. The financial support for the analysis of steel structural state was provided under RFBI grant (project No. 19-3260001), for the analysis of strengthening mechanisms under RSF grant (project No. 19-19-00183).

\section{REFERENCES}

1. V.E. Gromov, O.A. Peregudov, Yu.F. Ivanov, S.V. Konovalov, and A.A. Yuriev, Evolution of Rail Structural Phase States in Long Operation (Novosibirsk: SB RAS: 2017) (in Russian).

2. V.E. Gromov, A.B. Yuriev, K.V. Morozov, and Y.F. Ivanov, Microstructure of Quenched Rails (Cambridge: CISP Ltd: 2016).

3. Yu. Ivanisenko and H.J. Fecht, Steel Tech., 3, No. 1: 19 (2008).

4. Yu. Ivanisenko, I. Maclaren, X. Souvage, R.Z. Valiev, and H.J. Fecht, Acta Mater., 54: 1659 (2006).

https://doi.org/10.1016/j.actamat.2005.11.034

5. J.-li. Ning, E. Courtois-Manara, L. Kormanaeva, A.V. Ganeev, R.Z. Valiev, C. Kubel, and Yu. Ivanisenko, Mater. Sci. Eng. A, 581: 8 (2013).

https://doi.org/10.1016/j.msea.2013.05.008

6. V.G. Gavriljuk, Mater. Sci. Eng. A, 345: 81 (2003). https://doi.org/10.1016/S0921-5093(02)00358-1

7. Y.J. Li, P. Chai, C. Bochers, S. Westerkamp, S. Goto, D. Raabe, and R. Kirchheim, Acta Mater., 59: 3965 (2011).

https://doi.org/10.1016/j.actamat.2011.03.022 
8. V.G. Gavriljuk, Scripta Mater., 45: 1469 (2001). https://doi.org/10.1016/S1359-6462(01)01185-X

9. J.-W. Seo, H.-K. Jun, S.-J. Kwon, and D.-H. Lee, Int. J. Fatigue, 83: 184 (2016).

https://doi.org/10.1016/j.ijfatigue.2015.10.012

10. R. Lewis, P. Christoforou, W.J. Wang, A. Beagles, M. Burstow, and S.R. Lewis, Wear, 430-431: 383 (2019). https://doi.org/10.1016/j.wear.2019.05.030

11. J. Kalousek, D.M. Fegredo, and E.E. Laufer, Wear, 105: 199 (1985). https://doi.org/10.1016/0043-1648(85)90068-7

12. R. Skrypnyk, M. Ekh, J.C.O. Nielsen, and B.A. Pelsson, Wear, 428-429: 302 (2019). https://doi.org/10.1016/j.wear.2019.03.019

13. D. Kim, L. Quagliato, D. Park, and N. Kim, Wear, 420-421: 184 (2019). https://doi.org/10.1016/j.wear.2018.10.015

14. Y.B. Huang, L.B. Shi, X.J. Zhao, Z.B. Cai, Q.Y. Liu, and W.J. Wang, Wear, 400-401: 62 (2018).

https://doi.org/10.1016/j.wear.2017.12.020

15. V.E. Gromov, Yu.F. Ivanov, O.A. Peregudov, K.V. Morozov, X.L. Wang, W.B. Dai, Yu.V. Ponomareva, and O.A. Semina, Materials and Electronics Engineering, 2, No. 4: 1 (2015).

16. Yu.F. Ivanov, V.E. Gromov, O.A. Peregudov, K.V. Morozov, and A.B. Yuriev, Steel Transl., 45, No. 4: 245 (2015).

17. O.A. Peregudov, V.E. Gromov, Yu.F. Ivanov, K.V. Morozov, K.V. Alsaraeva, and O.A. Semina, AIP Conf Proc., 1683: 020179 (2015).

18. V.E. Gromov, K.V. Morozov, A.B. Yuriev, and O.A. Peregudov, Steel Transl., 45, No. 10: 759 (2015). https://doi.org/10.3103/S0967091215100058

19. Yu.F. Ivanov, O.A. Peregudov, K.V. Morozov, V.E. Gromov, N.A. Popova, and E.N. Nikonenko, IOP Conf. Ser.: Mater. Sci. Eng., 112: 012038 (2016). https://doi.org/10.1088/1757-899X/112/1/012038

20. V.E. Gromov, K.V. Morozov, Yu.F. Ivanov, K.V. Aksenova, O.A. Peregudov, and A.P. Semin, Diagnostics, Resource and Mechanics of Materials and Structures, 1: 38 (2016).

https://doi.org/10.17804/2410-9908.2016.1.038-044

21. V.E. Gromov, O.A. Peregudov, Y.F. Ivanov, A.M. Glezer, K.V. Morozov, K.V. Aksenova, and O.A. Semina, AIP Conf. Proc., 1783: 020069 (2016).

22. Yu.F. Ivanov, V.E. Gromov, A.M. Glezer, O.A. Peregudov, and K.V. Morozov, Bull. Russ. Acad. Sci.: Physics, 80, No. 12: 1483 (2016). https://doi.org/10.3103/S1062873816120078

23. O.A. Peregudov, V.E. Gromov, Y.F. Ivanov, K.V. Morozov, S.V. Konovalov, Steel Transl., 46, No. 4: 260 (2016).

24. O.A. Peregudov, K.V. Morozov, V.E. Gromov, A.M. Glezer, and Yu.F. Ivanov, Russ. Metall., 2016, No. 4: 371 (2016). https://doi.org/10.1134/S0036029516040182

25. V.E. Gromov, Y.F. Ivanov, K.V. Morozov, O.A. Peregudov, and O.A. Semina, J. Synch. Investig., 10, No. 5: 1101 (2016). https://doi.org/10.1134/S1027451016050281

26. V.E. Gromov, A.A. Yuriev, K.V. Morozov, Yu.F. Ivanov, S.V. Konovalov, O.A. Peregudov, and A.M. Glezer, Fundamental Problems of Modern Material Science, 14, No. 2: 267 (2017) (in Russian). 
27. V.E. Gromov, A.A. Yuriev, Yu.F. Ivanov, V.A. Grishunin, and S.V. Konovalov, Izvestiya. Ferrous Metallurgy, 61, No. 6: 454 (2018) (in Russian). https://doi.org/10.17073/0368-0797-2018-6-454-459

28. A.A. Yuriev, V.E. Gromov, K.V. Morozov, and O.A. Peregudov, Izvestiya. Chernaya Metallurgiya, 60, No. 10: 826 (2017) (in Russian). https://doi.org/10.17073/0368-0797-2017-10-826-830

29. Yu.F. Ivanov, V.E. Gromov, A.A. Yuriev, A.M. Glezer, N.A. Popova, O.A. Peregudov, and S.V. Konovalov, Deformation and Failure of Metals, No. 4: 24 (2018) (in Russian).

30. V.E. Gromov, A.A. Yuriev, Yu.F. Ivanov, N.A. Popova, O.A. Peregudov, A.M. Glezer, and S.V. Konovalov, Problems of Ferrous Metallurgy and Materials Science, No. 3: 76 (2017) (in Russian).

31. Yu.F. Ivanov, V.E. Gromov, A.A. Yuriev, O.A. Peregudov, S.V. Konovalov, K.V. Morozov, and V.A. Grishunin, Fundamental Problems of Modern Materials Science, 14, No. 3: 297 (2017) (in Russian).

32. A.A. Yuriev, V.E. Gromov, V.A. Grishunin O.A. Peregudov, Y.F. Ivanov, E.N. Nikitina, and L.P. Bashenko, Fundamental Problems of Modern Material Science, 14, No. 4: 438 (2017) (in Russian).

33. Yu.F. Ivanov, A.A. Yuriev, V.E. Gromov, S.V. Konovalov, and O.A. Peregudov, Izvestiya. Chernaya Metallurgiya, 61, No. 2: 140 (2018) (in Russian). https://doi.org/10.17073/0368-0797-2018-2-140-148

34. V.E. Gromov, A.A. Yuriev, Yu.F. Ivanov, Konovalov, and O.A. Peregudov, Metallofiz. Noveishie Tekhnol., 39, No. 12: 1599 (2017) (in Russian). https://doi.org/10.15407/mfint.39.12.1599

35. F.R. Egerton, Physical Principles of Electron Microscopy (Basel: Springer International Publishing: 2016).

36. C.S.S.R. Kumar, Transmission Electron Microscopy. Characterization of Nanomaterials (New York: Springer: 2014).

37. C.B. Carter and D.B. Williams, Transmission Electron Microscopy (Berlin: Springer International Publishing: 2016).

38. G. Thomas, M.J. Goringe, Transmission Electron Microscopy of Materials (Moscow: Nauka: 1983) (Russian translation).

39. P. Hirsch, A. Hovy, R. Nickolson, D. Pashley, and M. Whelan, Electron Microscopy of Fine Crystals (Moscow: Mir: 1968) (Russian translation).

40. N.A. Koneva, Eh.V. Kozlov, L.I. Trishkina, and D.V. Lychagin, Proc. Int. Conf. on the New Methods in Physics and Mechanics of a Deformable Solid (Tomsk: TGU: 1990), p. 83 (in Russian).

41. V.E. Gromov, Eh.V. Kozlov, V.I. Bazaikin, V.Ya. Tsellermayer, and Yu.F. Ivanov, Physics and Mechanics of Drawing and Die Forging (Moscow: Nedra: 1997) (in Russian).

42. N.A. Koneva and Eh.V. Kozlov, Proceedings of Higher Schools. Physics, No. 8: 3(1982) (in Russian).

43. V.G. Kurdyumov, L.M. Utevsky, and R.I. Entin, Transformations in Iron and Steel (Moscow: Nauka: 1977) (in Russian).

44. Eh.V. Kozlov, V.A. Starenchenko, and N.A. Koneva, Metals, No. 5: 152 (1993) (in Russian).

45. Yu.F. Ivanov, V.E. Gromov, N.A. Popova, S.V. Konovalov, and N.A. Koneva, Structural Phase States and Strengthening Mechanisms of Deformed Steel (Novokuznetsk: Polygraphist: 2016) (in Russian).

46. Yu.F. Ivanov, E.V. Kornet, Eh.V. Kozlov, and V.E. Gromov, Quenched Structural Steel: Structure and Mechanisms of Strengthening (Novokuznetsk: SibSIU: 2010) (in Russian). 
47. M.I. Goldstein and B.M. Farber, Dispersion Strengthening of Steel (Moscow: Metallurgy: 1979) (in Russian).

48. F.B. Pickering, Physical Metal Science and Treatment of Steels (Moscow: Metallurgy: 1982).

49. A.A. Predvoditelev, Modern State of Research of Dislocation Ensembles. Problems of Modern Crystallography (Moscow: Nauka: 1975) (in Russian).

50. D. Mc. Lin, Mechanical Properties of Metals (Moscow: Metallurgy: 1965) (Russian translation).

51. I.D. Embyri, Strengthening Method in Crystals. Applied Science Publications, 331 (1971).

52. Yu.F. Ivanov, V.E. Gromov, and E.N. Nikitina, Bainite Structural Steel: Structure and Mechanisms of Strengthening (Novokuznetsk: SibSIU: 2015) (in Russian).

53. N.A. Koneva and Eh.V. Kozlov, Physical Nature of Stage Development of Plastic Deformation (Novosibirsk: Nauka: 1990) (in Russian).

54. M.A. Shtremel, Strength of Alloys. Part II. Deformation. Textbook for Higher Schools (Moscow: MISiS: 1997) (in Russian).

55. N.F. Mott and F.R.N. Nabarro, Proc. Phys. Soc., 52, No. 1: 86 (1940).

56. B.Z. Belen'kii, B.M. Farber, and M.I. Goldstein, Fiz. Met. Metalloved., 39, No. 3: 403 (1975) (in Russian).

57. T. Ridley, H. Stuart, and L. Zwell, Trans. Met. Soc. AIME, 246, No. 8: 1834 (1969).

58. O. Vohringer and E. Macherauch, Hart.-Tech. Mitt., 32, No. 4: 153 (1977).

59. T. Prnka, Metal Science and Thermal Treatment of Steel, 7: 3 (1979).

60. V.E. Gromov, Yu. F. Ivanov, O.A. Peregudov, K.V. Morozov, and A.P. Semin, Usp. Fiz. Met., 17, No. 3: 253 (2016) (in Russian).

https://doi.org/10.15407/ufm.17.03.253

Received 03.06.2020;

in final version, 01.10.2020

В.С. Гролов ${ }^{1}$ Ю.Ф. Іванов ${ }^{2}$, В.С. Корлишев ${ }^{1}$,

А.О. Юрьєв ${ }^{3}$, О.П. Семін ${ }^{1}$, Ю.А. Рубаннікова ${ }^{1}$

${ }^{1}$ Сибірський державний індустріальний університет, вул. Кірова, 42, 654007 Новокузнецьк, РФ

${ }^{2}$ Інститут сильнострумової електроніки СВ РАН, просп. Академічний, 2/3, 634055 Томськ, РФ

${ }^{3} \mathrm{AT}$ «Свраз-Западно-Сибірський металургічний комбінат», Космічне шосе, 19, 654043 Новокузнецьк, РФ

ЗМІНА СТРУКТУРНО-ФАЗОВИХ СТАНІВ

І ВЛАСТИВОСТЕЙ ДОВГОМІРНИХ РЕЙОК

ПІД ЧАС НАДЗВИЧАЙНО ТРИВАЛОЇ ЕКСПЛУАТАЦІЇ

Методами сучасного фізичного матеріалознавства виявлено закономірності та механізми формування структурно-фазових станів і властивостей на різній глибині у голівці рейок по центральній осі та викружці після диференційованого гартування 100-метрових рейок й екстремально тривалої експлуатації (пропущений тоннаж - 1411 млн. тон брутто). Показано, що диференційоване гартування супроводжується формуванням морфологічно багатопланової структури, представленої зернами пластинчастого перліту, ферито-карбідної суміші та структурновільного фериту. Структуру криці характеризували параметром кристалічної гратниці $\alpha$-Fe, рівнем мікронапружень, розміром областей когерентного розсіян- 
ня, величиною міжплатівкової віддалі, скалярною та надлишковою густинами дислокацій. Показано, що екстремально тривала експлуатація рейок супроводжується множинним перетворенням структури металу головки рейок: по-перше, руйнуванням структури платівчастого перліту та формуванням в об'ємі перлітових колоній субзеренної структури субмікронних (100-150 нм) розмірів; подруге, виділенням по межах і в об'ємі субзерен частинок фази карбіду нанометрового діапазону; по-третє, зростанням мікроспотворень кристалічної гратниці криці; по-четверте, деформаційним наклепом металу, що спричинює збільшення (в 1,5 рази щодо вихідного стану) скалярної та надлишкової густин дислокацій. Тривала експлуатація рейок супроводжується формуванням градієнту структурних складових, що полягає у закономірній зміні відносного вмісту платівчастого перліту, зруйнованого перліту та структури ферито-карбідної суміші по перерізу головки рейок. По мірі наближення до поверхні викружки рейок відносний вміст об'єму металу зі структурою платівчастого перліту понижується, а зі структурою зруйнованого перліту та ферито-карбідної суміші збільшується. Встановлено, що характерною особливістю структури ферито-карбідної суміші є нанорозмірний діапазон зерен, субзерен і частинок фази карбіду, що формують їі - розмір зерен і субзерен, які формують даний тип структури, змінюється в межах 4070 нм; розмір частинок карбідної фази, розташованих на межі зерен і субзерен, змінюється в межах 8-20 нм. Виявлено багаточинниковий характер зміцнення криці, що зумовлено, по-перше, субструктурним зміцненням, спричиненим формуванням субмеж фраг'ментів, межі яких стабілізовано частинками карбідної фази; по-друге, зміцненням частинками карбідної фази, розташованими в обсязі фраґ'ментів і на елементах дислокаційної субструктури (дисперсійне зміцнення); по-третє, зміцненням, зумовленим осадженням на дислокаціях атомів Карбону (формуванням Коттреллових атмосфер); по-четверте, зміцненням, внесеним внутрішніми полями напружень, спричиненими несумісністю деформації кристалічних гратниць структурних складових $\alpha$-фази та частинок фази карбіду.

Ключові слова: рейки, мікро-нанокристалічна структура, платівчастий перліт, тривала експлуатація, механізми зміцнення. 